\title{
ANALISA PERAMALAN WINTER'S EXPONENTIAL SMOOTHING BROWN DIBANDINGKAN DENGAN AUTOREGRESSIVE INTEGRATED MOVING AVERAGE PADA DATA JUMLAH KEJADIAN HIPERTENSI
}

\author{
Wisoedhanie Widi .A, Prodi DIII Keperawatan, Sekolah Tinggi Ilmu Kesehatan Panti Waluya \\ Malang \\ Email: wisoedhanie.widi@gmail.com \\ Nanik Dwi A., Prodi DIII Keperawatan, Sekolah Tinggi Ilmu Kesehatan Panti Waluya Malang \\ Email: nanikd79@gmail.com
}

\begin{abstract}
In an attempt to see and examine the situation and conditions that occur in the future to do forecasting (forecasting). Hypertension is a major disease in the ten Clinics Together and almost every month new hypertension cases occur, so the incidence of hypertension is becoming the trend and forecasting needs to be done.

The purpose of this research is to do forecasting on the data the number of incident hypertension in Clinics With the city of Malang with Exponential Smoothing method using winter's Brown compared to Autoregressive Integrated Moving Arima. This type of research is the study of non reactive (non reactive research) which is a type of secondary data for research.Unit samples in this research are patients who come for the medication and patients in Clinics With hypertension Malang. in 2013 to 2016. Research data using Minitab software.

The results of this study showed that both methods of forecasting results shows that tend to decrease in the year 2018 with the lowest incidence in December that as many as 58 incidents on Exponential Smoothing method of winter's and some 80 events on the method of Autoregressive Integrated Moving Average.

The existence of a trend of decrease in the incidence of hypertension can be supported by the growing health services at community health centers With has been doing various efforts in preventive action, promotif and collaborative in the handling of problems Hypertension.Through these research results, it is advisable to draw up a health center party planning and control and eradication programs work for transmission of diseases of hypertension $(P 2 P)$ with reference to the results of the forecasting incidence of hypertension in the year 2018.
\end{abstract}

\section{Keywords: Forecasting, Hypertension, Exponential Smoothing}

\section{PENDAHULUAN}

Peramalan (forecasting) adalah suatun kegiatan dalam mengestimasi kejadian yang terjadi di masa mendatang. Prediksi diperlukankarena adanya perbedaan kesenjangan waktu (time lag) sehingga dibutuhkannya suatu kebijakan baru untuk waktu pelaksanaan kebijakan tersebut (Makridakis, 1999). Peramalan menjadi sangat penting bagi perencanaan yang efektif dan efesien dan menjadi dasar bagi perencanaan jangka panjang maupun jangka panjang bagi pemangku kebijakan (Makridakis, 1998).

Pada dasarnya peramalan ada dua macam yaitu peramalan secara kualitatif dan peramalan kuantitatif. Salah satu metode peramalan kuantitaif yang dapat digunakan adalah peramalan yang didasarkan pada deret waktu (time series). Time series adalah rangkaian atau seri dari nilai-nilai variabel atau hasil observasi, dalam hal ini adalah segala sesuatu yang akan dilakukan pencatatan dalam jangka waktu yang berurutan (Atmaja, 2009). Metode time series didasarkan pada penggunaan analisa pola hubungan antar variabel yang dapat diperkirakan dengan menggunakan variabel waktu yang merupakan bagian dari deret waktu. Berdasarkan garis besarnya metode time seriesdapat dikelompokkan menjadi metode averaging, metode smoothing, dan metode regressi (BoxJenkins, 1994).

Metode exponential smoothing adalah suatu metode yang menggunakan bobot yang 
berbeda pada setiap periodenya dan membentuk fungsi eksponensial. Bila pola datanya stationer, dapat menggunakan single exponential smoothing untuk meramalkan, apabila datanya tidak stationer dan mengandung trend maka dapat menggunakan double exponential smoothing, apabila datanya mengandung trend dan memiliki pola siklis maka menggunakan triple exponential smoothing (Box-Jenkins, 1994).

Autoregressive Integrated Moving Average atau dikenal dengan istilah ARIMA merupakan salah satu teknik model peramalan berdasarkan perilaku data variabel yang diamati. Model ARIMA menggunakan nilai masa lalu dansekarang dari variabel dependen untuk menghasilkan peramalan jangka pendek yang akurat. Model ARIMA dilakukan pada data stasioner atau data yang didefferencing sehingga data telah stasioner. Secara umum tujuan peramalan adalah menentukan hubungan antar variabel yang diramal dengan nilai historis sehingga peramalan selanjutnya dapat dilakukan dengan model tersebut.

Analisis time series ini dapat diterapkan pada penyakit hipertensi. Hipertensi sebagai the silent killer merupakan faktor utama masalah morbiditas dan mortalitas (Bonita, 2001; Balitbangkes, Depkes RI, 2006). Hipertensi yang tidak terkontrol dengan baik dapat menyerang target organ dan menyebabkan serangan jantung, hipertensi, masalah ginjal, serta kebutaan. Hipertensi yang tidak terkontrol mampu meningkatkan peluang tujuh kali lebih besar bagi seseorang terkena hipertensi, enam kali lebih besar terkena congestive heart failure, dan tiga kali lebih besar terkena serangan jantung (CDC, 1999; WHO/SEARO, 2005).

Menurut WHO dan The International Society of Hypertention (ISH), pada saat ini terdapat 600 juta penderita hipertensi di seluruh dunia, dan sejumlah 3 juta meninggal setiap tahunnya. Tujuh dari setiap sepuluh penderita tidak mendapatkan pengobatan yang optimal (WHO-ISH, 2003; JNC-7, 2003). Di negara Indonesia masalah hipertensi cenderung meningkat (Kapita Selekta, 1999). Data Survei Kesehatan Rumah Tangga (SKRT) tahun 2001 menunjukkan bahwa 8,3\% penduduk Indonesia mengalami hipertensi dan meningkat menjadi 27,5\% pada tahun 2004
(Depkes RI, 2004). Hasil survey tahun 1995, 2001, 2004, menunjukkan penyakit kardiovaskuler merupakan penyebab kematian nomer satu di Indonesia dan sekitar 20-35\% dari kematian tersebut dikarenakan hipertensi. Riskesdas tahun 2013 menunjukkan data prevalensi hipertensi di Indonesia sebesar 26,5\%.

Puskesmas Bareng merupakan salah satu penyelenggara upaya pelayanan kesehatan masyarakat tingkat pertama serta upaya kesehatan perorangan tingkat pertama. Upaya kesehatan masyarakat tingkat pertama dilaksanakan kepada masyarakat esensial dan upaya pengembangan kesehatan masyarakat. Upaya kesehatan esensial diantaranya meliputi pelayanan promosi kesehatan, kesehatan lingkungan, kesehatan ibu, anak dan keluarga berencana, gizi serta pencegahan penyakit.

Fenomena yang diperoleh pada saat peneliti melakukan survey asuhan keperawatan pada keluarga resiko tinggi di wilayah kerja Puskesmas Bareng, diperoleh satu keluarga dengan masalah kesehatan hipertensi. Keterangan yang diperoleh dari pembimbing puskesmas mengatakan bahwa kasus hipertensi di Puskesmas Bareng tergolong banyak. Hampir setiap bulan terjadi kasus baru hipertensi. Hasil studi pendahuluan yang dilakukan di Puskesmas Bareng, menunjukkan bahwa pada tahun 2016 hipertensi menempati urutan pertama pada 10 besar penyakit di Puskesmas Bareng dengan jumlah penderita baru dan lama mencapai 2539. Berdasarkan data tersebut peneliti ingin melakukan peramalan (forecasting) menggunakan analisa deret waktu (time series) winter's exponential smoothing pada angka kejadian hipertensi berdasarkan data jumlah kejadian hipertensi pada tahun sebelumnya di Puskesmas Bareng, dengan terlebih dahulu mengidentifikasi pola penyakit hipertensi yang ada di Puskesmas Bareng untuk kemudian dilakukan peramalan jumlah kejadian hipertensi di Puskesmas Bareng.

\section{METODE PENELITIAN}

Desain penelitian yang digunakan dalam penelitian ini adalah non reaktif (non reactive research) yang merupakan jenis penelitian untuk data sekunder. Penelitian non rekatif disebut juga penelitian unobstrusive 
dimana sejumlah individu yang diteliti tidak sadar bahwa mereka merupakan bagian dari penelitian, tetapi meninggalkan bukti dari perilaku sosial secara ilmiah. Dengan kata lain, dalam penelitian unobstrusive tidak terdapat reaksi dari subjek penelitian. Penelitian bersifat tidak mengganggu subjek penelitian dan subjek penelitian juga tidak merasa terganggu (Kuntoro, 2011).

Berdasarkan waktu penelitian, maka penelitian ini merupakan penelitian cross sectional. Berdasarkan tujuan dan sifat masalah, penelitian ini adalah penelitian analitik dengan pendekatan observasional. Penelitian ini juga dikategorikan sebagai penelitian terapan (applied research), karena mencoba menerapkan metode statistic tertentu, dalam hal ini adalah metode peramalan dalam bidang kesehatan, yaitu kejadian hipertensi.

Penelitian ini dilakukan di Puskesmas Bareng Kota Malanpada bulan Pebruari 2018 sampai dengan Agustus 2018. Yang menjadi populasi dalam penelitian ini adalah semua pasien yang berobat dan tercatat sebagai pasien hipertensi di Puskesmas Bareng Kota Malang. Sedangkan sampel dalam penelitian ini adalah pasien yang periksa dan tercatat sebagai pasien hipertensi di Puskesmas Bareng Kota Malang.pada tahun 2013 hingga 2016. Variabel dalam penelitian ini, yaitu variabel waktu dan variabel jumlah kejadian hipertensi. Variabel waktu dapat dikatakan sebagai variabel bebas yang akan mempengaruhi angka kejadian hipertensi di masa yang akan datang.

Data dalam penelitian ini menggunakan data sekunder, dengan demikian peneliti menggunakan data yang telah tercatat dan didokumentasikan secara resmi sebagai data sistem informasi kesehatan tentang jumlah kejadian penyakit hipertensi di Puskesmas Bareng Kota Malang. Data yang digunakan oleh peneliti adalah data jumlah kejadian hipertensi pada tahun 2013 hingga 2016. Peneliti merekap data pasien yang datang berobat dan tercatat sebagai pasien hipertensi mulai tahun 2013 hingga tahun 2016.

Data penelitian diolah dengan menggunakan metode peramalan. Metode peramalan yang digunakan yaitu Holth Winters Exponential Smoothing. Metode peramalan

Holth

Winters Exponential

Smoothing diolah menggunakan software

Minitab.

\section{HASIL PENELITIAN}

\section{Gambaran Penderita Hipertensi di Puskesmas Bareng}

Data penderita hipertensi yang digunakan pada penelitian ini adalah data kejadian hipertensi di Puskesmas Bareng Kota Malang pada 4 (empat) tahun sebelumnya, yaitu data kejadian hipertensi pada tahun 2013, 2014, 2015 dan 2016. Berdasarkan laporan kejadian hipertensi pada tahun 2013, 2014, 2015 dan 2016 dapat diperoleh besarnya jumlah kejadian hipertensi di Puskesmas Bareng Kota Malang dapat dilihat pada tabel 1.

Tabel 1: Angka kejadian penyakit Hipertensi di Puskesmas Bareng Kota Malang

\begin{tabular}{clcccc}
\hline \multirow{2}{*}{ No } & \multirow{2}{*}{ Bulan } & \multicolumn{4}{c}{ Tahun } \\
\cline { 3 - 6 } & & $\mathbf{2 0 1 3}$ & $\mathbf{2 0 1 4}$ & $\mathbf{2 0 1 5}$ & $\mathbf{2 0 1 6}$ \\
\hline 1 & Januari & 502 & 502 & 502 & 225 \\
\hline 2 & Februari & 439 & 382 & 439 & 188 \\
\hline 3 & Maret & 426 & 426 & 426 & 276 \\
\hline 4 & April & 364 & 324 & 364 & 232 \\
\hline 5 & Mei & 414 & 414 & 414 & 224 \\
\hline 6 & Juni & 445 & 445 & 445 & 198 \\
\hline 7 & Juli & 445 & 439 & 439 & 173 \\
\hline 8 & Agustus & 408 & 408 & 463 & 224 \\
\hline 9 & September & 492 & 492 & 454 & 190 \\
\hline 10 & Oktober & 316 & 316 & 405 & 287 \\
\hline 11 & Nopember & 423 & 407 & 459 & 254 \\
\hline 12 & Desember & 385 & 385 & 432 & 185 \\
\hline
\end{tabular}

Sumber : Data laporan Puskesmas Bareng Kota Malang

Tabel 1 menunjukkan bahwa kejadian hipertensi di Puskesmas Bareng Kota Malang menunjukkan fluktuasi yang berubah-ubah di setiap bulan dari tahun 2013, 2014, 2015 dan 2016.

\section{Peramalan Time Series Menggunakan Winter's Exponential Smoothing}

1. Identifikasi Plot Data atau Scatter Diagram Plot pada data asli kejadian hipertensi di Puskesmas Bareng Kota Malang pada bulan Januari 2013 sampai dengan bulan Desember 2016, diperoleh hasil yang dapat dilihat pada gambar 1 . 


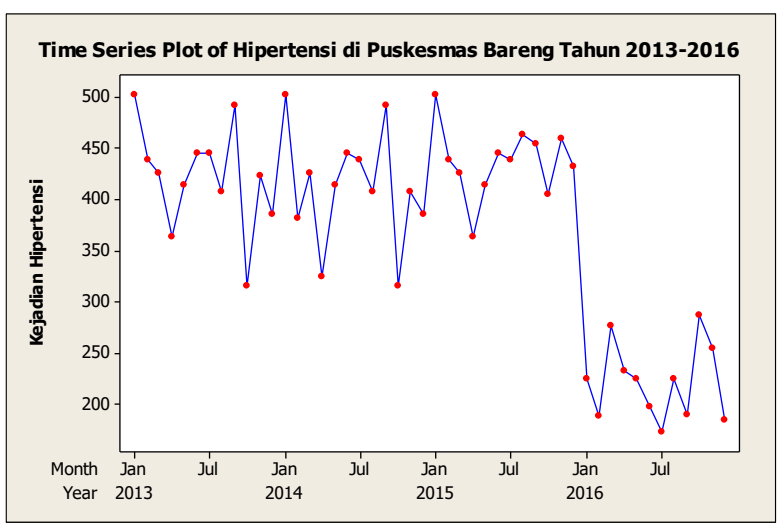

Gambar 1 Plot Data Kejadian Hipertensi

Gambar 1 menunjukkan dalam tahun yang sama, pada saat tertentu dalam satu tahun tersebut terjadi peningkatan dan penurunan berulang pada saat yang lain pada waktu yang sama, hal tersebut berulang pada tahun berikutnya. Terlihat peningkatan kejadian hipertensi setiap tahunnya pada bulan Januari dan mengalami fluktuasi yang sama pada bulan Juli hingga tahun 2015, hal ini menunjukkan bahwa pola data bersifat seasonal atau musiman. Pada bulan Januari tahun 2016 terjadi penurunan kejadian hipertensi, namun data tetap berfluktuasi dengan angka kejadian yang lebih rendah dari tahun-tahun sebelumnya.

Gambaran plot data kejadian hipertensi di Puskesmas Bareng pada Tahun 2013 hingga tahun 2016 menunjukkan bahwa data mengandung unsur seasonal atau musiman sehingga dapat ditentukan metode peramalan yang dapat digunakan adalah metode winters exponential smoothing bukan metode double exponential smoothing. Nilai uji root dengan statistic Augmented Dickey Fuller menunjukkan nilai probabilitas sebesarlebih besar daripada nilai sehingga dapat dikatakan data tidak stasioner Nilai statistic kurang dari nilai kritis Mackinnon dengan adalah artinya menunjukkan bahwa data tidak stasioner. Data yang tidak stasioner mengindikasikan bahwa data tidak sesuai apabila dilakukan peramalan dengan menggunakan pendekatan single exponential smoothing. Adanya pola musiman dari data kejadian hipertensi merujuk pada pendekatan metode peramalan holt winters exponential smoothing.

\section{Menentukan Panjang Musiman}

Data kejadian hipertensi di Puskesmas Bareng memiliki panjang musiman atau periode musiman adalah 12 karena data disusun berdasarkan data setiap bulan, dengan periode waktu selama 4 tahun, yaitu mulai tahun 2013, 2014, 2015 dan 2016.

\section{Menentukan Nilai Awal Pemulusan}

Nilai awal taksiran untuk model multiplikatif diperoleh nilai inisialisasi pemulusan adalah 421,5833 yang merupakan rata-rata dari beberapa nilai musim yang sama. Inisialisasi faktor trend adalah -0,82639 dan inisialisasi faktor $l_{k}$ musiman untuk penghalusan musiman yaitu $l_{1}=1,190749$; $l_{2}=1,041313 ; \quad l_{3}=1,010476 ; \quad l_{4}=0,863412$; $l_{5}=0,982012 ; \quad l_{6}=1,055545 ; \quad l_{7}=1,055545 ;$ $l_{8}=0,96778 ; \quad l_{9}=1,167029 ; \quad l_{10}=0,749555 ;$ $l_{11}=1,00336 ; l_{12}=0,913224$

\section{Pendugaan Parameter $\alpha, \beta, \gamma$}

Parameter terbaik untuk nilai $\alpha, \beta, \gamma$ pada peramalan dilakukan dengan metode trial dan error. Nilai konstanta pemulusan didasarkan pada MAPE, MAD dan MSE yang diperoleh melalui aplikasi minitab ditunjukkan pada tabel

Tabel 3. Konstanta Parameter $\alpha, \beta, \gamma$

\begin{tabular}{cccccc}
\hline$(\boldsymbol{\alpha})$ & $(\boldsymbol{\gamma})$ & $(\boldsymbol{\beta})$ & MAPE & MAD & MSE \\
\hline 0,1 & 0,1 & 0,1 & 19,13 & 51,74 & 5582,89 \\
\hline 0,2 & 0,2 & 0,2 & 14,08 & 39,11 & 4399,91 \\
\hline 0,3 & 0,3 & 0,3 & 12,76 & 36,72 & 4240,37 \\
\hline 0,2 & 0,2 & 0,3 & 14,27 & 39,61 & 4552,56 \\
\hline 0,2 & 0,3 & 0,3 & 14,25 & 39,70 & 4147,17 \\
\hline 0,3 & 0,2 & 0,3 & 12,46 & 36,04 & 4098,48 \\
\hline 0,3 & 0,1 & 0,3 & 12,77 & 36,50 & 3926,36 \\
\hline 0,3 & 0,1 & 0,1 & 12,45 & 35,77 & 3662,71 \\
\hline 0,3 & 0,2 & 0,2 & 12,25 & 35,49 & 3949,93 \\
\hline 0,2 & 0,1 & 0,1 & 14,24 & 39,54 & 4157,14 \\
\hline 0,2 & 0,1 & 0,3 & 14,57 & 40,21 & 4440,39 \\
\hline 0,2 & 0,3 & 0,2 & 14,01 & 39,07 & 4568,79 \\
\hline 0,3 & 0,2 & 0,1 & 12,04 & 35,00 & 3806,39 \\
\hline 0,3 & 0,1 & 0,2 & 12,62 & 36,17 & 3793,42 \\
\hline
\end{tabular}

\section{Menentukan Parameter $\alpha, \beta, \gamma$}

Perhitungan semua $\alpha, \beta$, $\gamma$ yang telah dilakukan menghasilkan 27 kombinasi model. Beberapa model yang terbentuk tersebut dipilih model yang terbaik, yang merupakan kombinasi $\alpha=0,3 ; \gamma=0,2$ dan $\beta=0,1$ dengan nilai Mean Average Percentage Error (MAPE) sebesar 12,04, nilai Mean Average Deviation 
(MAD) sebesar 35,00 dan nilai Mean Square Error (MSE) sebesar 3806,39.

Nilai MAPE sebesar 12,04 menunjukkan bahwa rata-rata absolut perbedaan nilai asli dan nilai peramalan pada data bulan pertama tahun 2013 hingga bulan terakhir tahun 2016 adalah sebesar 12,04\%. Nilai MAD menunjukkan besarnya rata-rata absolut penyimpangan dari nilai asli sebesar 35, dan MSE menunjukkan kuadrat dari ratarata kesalahan yaitu sebesar 3806,39

\section{Menentukan Persamaan Model}

Model dengan $\alpha=0,3 ; \gamma=0,2$ dan $\beta=$ 0,1 adalah model terbaik. Sehingga persamaan model pemulusan eksponential data asli adalah $S_{t}=0,3 \frac{x_{t}}{l_{t-l}}+0,7\left(S_{t-1}+b_{t-1}\right)$, pemulusan polatrend yaitu $b t=0,1\left(S_{t}-S_{t-1}\right)+0,9 b_{t-1}$ dan pemulusan pola musiman yaitu $l_{t}=0,2\left(X_{t}-S_{t}\right)+0,8 l_{m t-12}$ dan peramalan $\mathrm{m}$ untuk periode ke depan yaitu $F_{t+m}=S_{t}+b_{t} m+l_{m t-L+m}$

\section{Menentukan Nilai Peramalan Kejadian} Hipertensi pada Tahun 2018

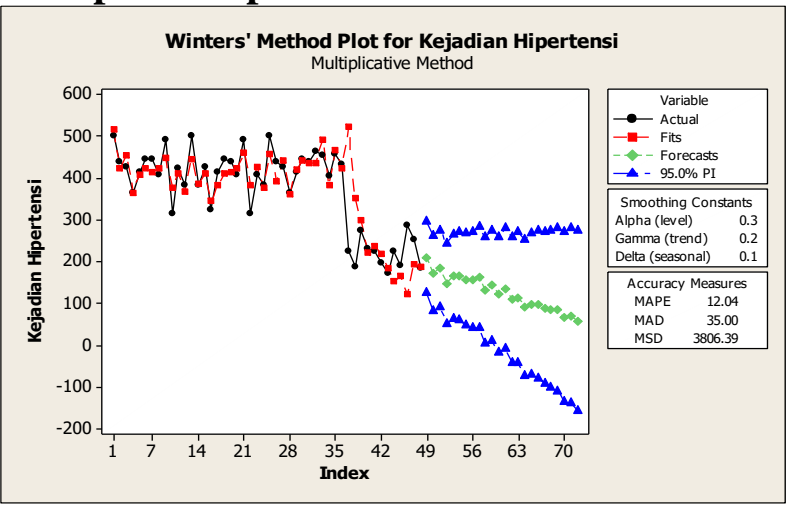

Gambar 2 Output Exponential Smooting Pada Kejadian Hipertensi

Gambar 2 menunjukkan hasil peramalan winters exponential smoothingyang menghasilkan plot time series tetapan awal dimana menampilkan nilai-nilai series yang sesuai (fitted) satu periode di depan peramalan bersamaan dengan 12 peramalan. Peramalan tersebut menggunakan parameter pemulusan yang bernilai $\quad \alpha=0,3, \gamma=0$.

Secara deskriptif menunjukkan bahwa kejadian hipertensi menunjukkan penurunan mulai pada bulan ke 49 hingga bulan ke 70 . Data peramalan yang lebih detail akan ditunjukkan pada tabel 4 di bawah ini :
Tabel 4 Hasil Peramalan Kejadian Hipertensi

\begin{tabular}{clc}
\hline No & $\begin{array}{c}\text { Waktu } \\
\text { (Th 2018) }\end{array}$ & $\begin{array}{c}\text { Kejadian } \\
\text { Hipertensi }\end{array}$ \\
\hline 1 & Januari & 135,068 \\
\hline 2 & Februari & 108,818 \\
\hline 3 & Maret & 113,910 \\
\hline 4 & April & 90,405 \\
\hline 5 & Mei & 97,956 \\
\hline 6 & Juni & 96,853 \\
\hline 7 & Juli & 89,304 \\
\hline 8 & Agustus & 86,231 \\
\hline 9 & September & 85,938 \\
\hline 10 & Oktober & 67,521 \\
\hline 11 & Nopember & 70,399 \\
\hline 12 & Desember & 57,228 \\
\hline
\end{tabular}

Tabel 4 menunjukkan bahwa hasil peramalan kejadian hipertensi untuk tahun 2018 mengalami trend penurunan, dengan kejadian tertinggi terjadi pada bulan Januari yaitu sebanyak 135,068 136 kejadian dan kejadian terendah terjadi pada bulan Desember yaitu sebanyak 57,228 58 kejadian

\section{Akurasi Nilai Peramalan}

Akurasi penilaian diperoleh dari nilai MAPE, MSE dan MAD yang menunjukkan nilai terkecil, yaitu nilai Mean Average Percentage Error (MAPE) sebesar 12,04, nilai Mean Average Deviation (MAD) sebesar 35,00 dan nilai Mean Square Error (MSE) sebesar 3806,39.

\section{Peramalan Time Series Menggunakan Autoregressive Integrated Moving Average 1). Mengidentifikasi Model} a. Identifikasi Plot Data atau Scatter Plot

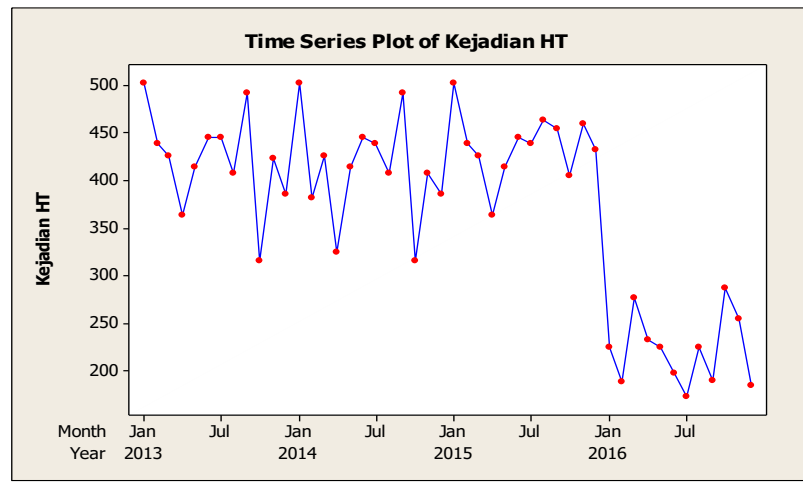

Gambar 3 Plot Data Bulanan Kejadian Hipertensi di Puskesmas Bareng Tahun 20132016 
Berdasarkan gambar 3 menunjukkan bahwa pada data kejadian hipertensi terdapat fluktuasi, sehingga dapat dikatakan data tidak stasioner terhadap ragam dan rata-rata, maka kita lakukan transformasi data.

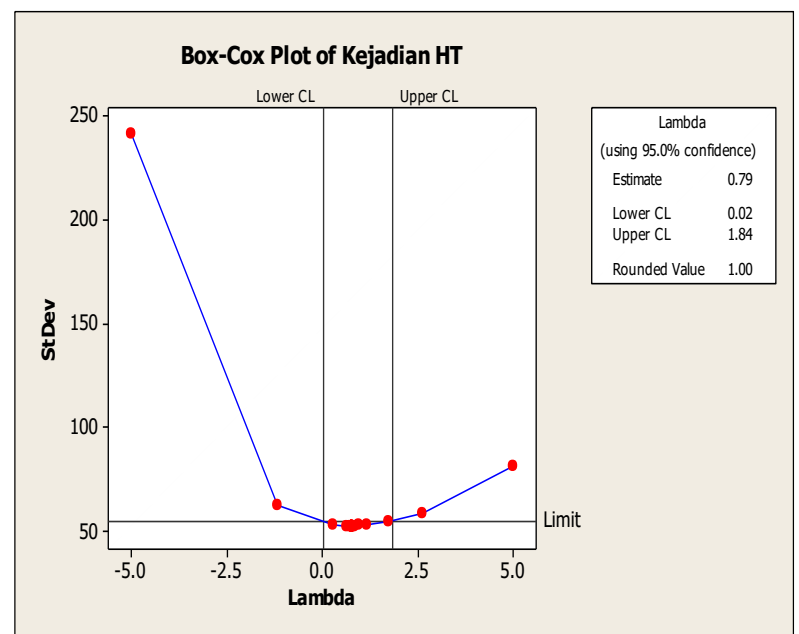

Gambar 4 Box Cox Plot Kejadian Hipertensi di Puskesmas Bareng Tahun 2013-2016

Hasil transformasi menunjukkan rounded value pada angka 1,00 artinya data telah stationer terhadap ragam, langkah selanjutnya melakukan pengecekan stasioner data terhadap rata-rata.

\section{b. Menghitung ACF data}

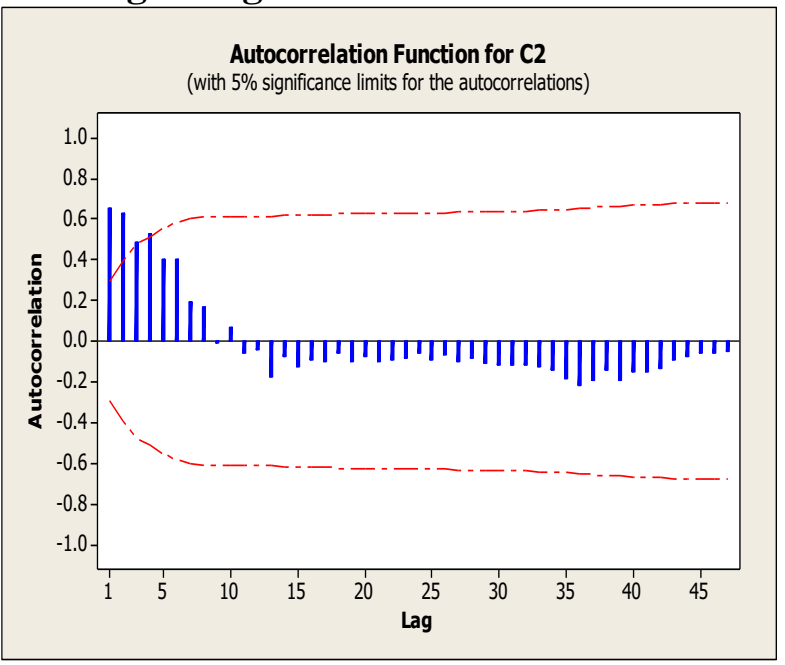

Gambar 5Plot ACF Kejadian Hipertensi di Puskesmas Bareng Tahun 2013-2016.

Plot ACF menunjukkan data belum stasioner terhadap rata-rata yaitu 3 lag pertama keluar dari selang kepercayaan. Langkah yang dapat dilakukan adalah melakukan differencing, dengan hasil ACF differencing sebagai berikut:

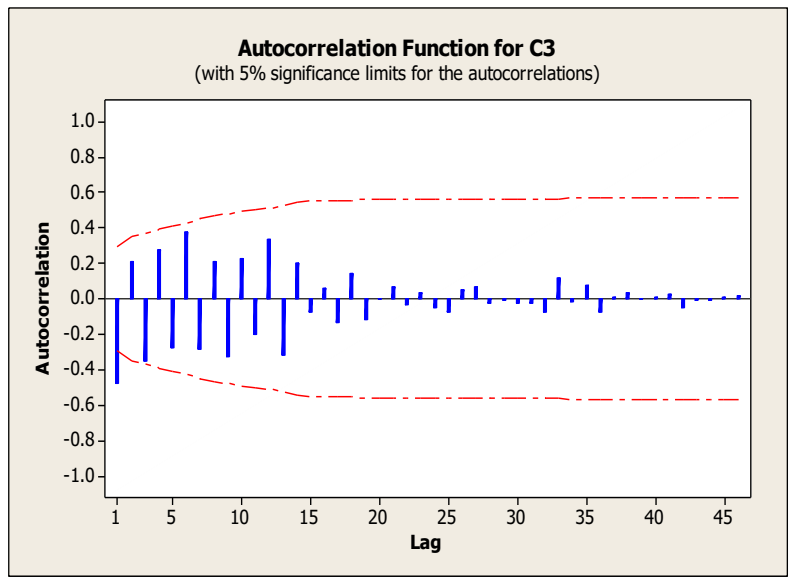

Gambar 6 Plot ACF Diferencing Kejadian Hipertensi di Puskesmas Bareng Tahun 20132016.

\section{c. Menghitung PACF data}

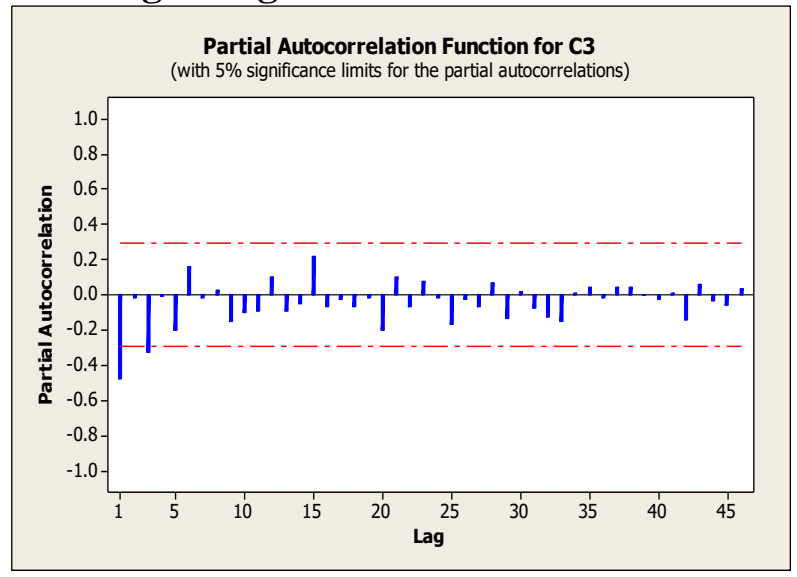

Gambar 7 Plot PACF Kejadian Hipertensi di Puskesmas Bareng Tahun 2013-2016.

Berdasarkan hasil plot ACF dan PACF kejadian hipertensi menunjukkan bahwa dugaan model ARIMA yang sesuai adalah $(3,1,1)$.

\section{2). Mengestimasi Parameter ARIMA Model: C2}

Estimates at each iteration

Iteration SSE Parameters

$\begin{array}{lllllll}0 & 275123 & 0.100 & 0.100 & 0.100 & 0.100 & -4.651\end{array}$

$\begin{array}{llllllll}1 & 222013 & -0.029 & 0.026 & -0.050 & 0.146 & -7.216\end{array}$

$\begin{array}{lllllll}2 & 190109 & -0.081 & -0.029 & -0.200 & 0.273 & -7.973\end{array}$

$\begin{array}{llllllll}3 & 179700 & -0.231 & -0.071 & -0.301 & 0.256 & -8.941\end{array}$

$\begin{array}{lllllll}4 & 178658 & -0.293 & -0.099 & -0.343 & 0.241 & -9.326\end{array}$

$\begin{array}{lllllll}5 & 178634 & -0.307 & -0.109 & -0.351 & 0.231 & -9.402\end{array}$

$\begin{array}{lllllll}6 & 178633 & -0.312 & -0.112 & -0.352 & 0.227 & -9.434\end{array}$

$\begin{array}{lllllll}7 & 178633 & -0.314 & -0.113 & -0.353 & 0.225 & -9.449\end{array}$

$\begin{array}{lllllll}8 & 178633 & -0.315 & -0.113 & -0.353 & 0.224 & -9.456\end{array}$

$\begin{array}{lllllll}9 & 178633 & -0.315 & -0.113 & -0.353 & 0.224 & -9.459\end{array}$

$\begin{array}{lllllll}10 & 178633 & -0.315 & -0.113 & -0.353 & 0.224 & -9.460\end{array}$ 
Relative change in each estimate less than 0.0010 Final Estimates of Parameters

\begin{tabular}{|c|c|c|c|c|}
\hline & & & & \\
\hline AR 1 & & & & \\
\hline & & & & \\
\hline & & & -2.27 & \\
\hline $\begin{array}{l}A \\
A\end{array}$ & & & & \\
\hline onstan & 9.46 & 7.3 & -1.2 & 0.2 \\
\hline
\end{tabular}

Differencing: 1 regular difference

Number of observations: Original series 48 , after differencing 47

Residuals: $\quad$ SS $=176494$ (backforecasts excluded)

$\mathrm{MS}=4202 \mathrm{DF}=42$

Modified Box-Pierce (Ljung-Box) Chi-Square statistic

$\begin{array}{lllll}\text { Lag } \quad 12 & 24 & 36 & 48\end{array}$

Chi-Square $6.3 \quad 14.9 \quad 24.2 *$

$\begin{array}{lllll}\text { DF } & 7 & 19 & 31 & *\end{array}$

P-Value $0.508 \quad 0.727 \quad 0.802 *$

\section{3). Melakukan Prediksi}

Tabel 5 Hasil Peramalan Kejadian Hipertensi di Puskesmas Bareng Kota Malang 2018.

\begin{tabular}{|c|l|c|}
\hline No & $\begin{array}{c}\text { Waktu } \\
\text { (Tahun 2018) }\end{array}$ & $\begin{array}{c}\text { Kejadian } \\
\text { Hipertensi }\end{array}$ \\
\hline 1 & Januari & 138,932 \\
\hline 2 & Februari & 133,363 \\
\hline 3 & Maret & 128,067 \\
\hline 4 & April & 122,565 \\
\hline 5 & Mei & 117,405 \\
\hline 6 & Juni & 112,064 \\
\hline 7 & Juli & 106,814 \\
\hline 8 & Agustus & 101,435 \\
\hline 9 & September & 96,150 \\
\hline 10 & Oktober & 90,818 \\
\hline 11 & Nopember & 85,536 \\
\hline 12 & Desember & 80,210 \\
\hline
\end{tabular}

\section{PEMBAHASAN}

Tabel 1 menggambarkan jumlah kejadian hipertensi di puskesmas Bareng Kota Malang mulai tahun 2013 hingga 2016 yang disusun menggunakan jumlah kejadian berdasarkan urutan waktu (bulan), sehingga data kejadian hipertensi tergolong pada data time series. Hal tersebut sesuai dengan yang disampaikan oleh Sriandari (2015) bahwa data time series adalah data yang dikumpulkan kemudian dilakukan pencatatan dan diamati dari waktu ke waktu secara urut dengan batasan waktu mingguan, bulanan atau tahunan yang diperoleh dari kejadian kasus setiap hari atau jam dapat disebut data urut waktu. Data urut waktu dapat digunakan untuk menentukan pola variasi data di masa lalu dan selanjutnya dapat digunakan untuk memprediksi nilai di waktu yang akan datang (forecast).

Data kejadian hipertensi di puskesmas Bareng Kota Malang mulai tahun 2013 hingga 2016 mengalami fluktuasi setiap bulannya yang ditunjukkan oleh hasil plot series yang menampilkan adanya pola musiman dan tidak stasioner. Data kejadian hipertensi di puskesmas Bareng Kota Malang pada tahun 2013 hingga 2016 memiliki 48 titik pengamatan yang disusun berdasarkan laporan setiap bulan, dengan demikian dapat dikatakan bahwa data time series kejadian hipertensi di puskesmas Bareng Kota Malang memiliki panjang musiman sebanyak 12 .

Menurut Box (1976), komponen musiman ditandai oleh adanya periode fluktuasi dengan waktu sangat singkat selama 1-2 tahun atau bisa juga kurang. Gerakan musiman merupakan gerakan dengan periode kurang dari 1 tahun dengan pola tetap atau identik setiap waktu dan kurang dari satu tahun, artinya pola yang berulang dalam jangka pendek atau kurang dari 1 tahun dapat disebut pola musiman.

Penelitian time series memiliki beberapa pendekatan dalam menentukan metode yang akan digunakan. exponential smoothing merupakan metode yang menggunakan bobot yang berbeda pada setiap periode waktunya dan membentuk fungsi exponential. Peramalan dilakukan dengan menggunakan pendekatan exponential smoothing karena data pengamatan yang digunakan kurang dari 50 pengamatan. Hasil plot data menunjukkan pola data yang non stasioner, berfluktuasi setiap bulannya dan mengandung unsur seasonal (musiman) maka pendekatan yang digunakan adalah triple exponential smoothing (Makridakis, 1999). Metode penghalusan exponential tripel dari winters lebih dikenal dengan metode Holt-Winters (Makridakis, dkk, 1999). Metode Winters menggunakan sebuah komponen level, sebuah komponen tren dan sebuah komponen musiman pada tiap periode. Menggunakan tiga bobot atau 
parameter penghalusan untuk memperbaharui komponen pada tiap periode (Saludin, 2017) Penentuan nilai awal pada peramalan winters dapat dilakukan dengan menggunakan data paling sedikit satu kelompok data musiman lengkap yaitu pada penelitian ini menggunakan data pada tahun 2013 dan selanjutnya dihitung dengan menggunakan rumus. $\frac{1}{l}\left(X_{1}+X_{2}+X_{3} \ldots+X_{l}\right) \quad$ Menurut

Sriandari (2015) proses penentuan nilai awal atau yang biasa disebut proses inisialisasi sangat diperlukan untuk menentukan nilai pemulusan keseluruhan yaitu $s_{t}=\propto\left(\frac{x_{t}}{l_{t-1}}\right)+(1-\propto)\left(S_{t-1}+b_{t-1}\right)$

Penentuan parameter $\alpha, \beta, \gamma$ menggunakan cara simulasi yaitu dengan memasukkan semua kemungkinan nilai konstanta untuk dapat dipilih nilai mana yang dapat meminimumkan nilai MAPE, MAD dan MSE. Kerugian yang diperoleh dari perhitungan dengan cara simulasi atau trial dan error adalah memakan waktu yang lama akan tetapi dapat menghasilkan nilai konstanta yang maksimal (Makridakis, 1999).

Hasil simulasi menunjukkan bahwa kombinasi nilai $\alpha=0,3, \gamma=0,2, \beta=0,1$ dapat menghasilkan nilai MAPE, MAD dan MSE yang terkecil. Hasil tersebut sesuai dengan yang dikemukakan oleh Makridakis (1999) bahwa metode alternative yang dapat dilakukan untuk mengurangi keraguan nilai optimal yaitu mencari taksiran awal yang lebih baik kemudian menetapkan nilai yang lebih kecil untuk ketiga parameter pemulusan yaitu sekitar 0,1 sampai 0,3 . Nilai 0,1 sehingga peramalan bersifat terlalu hati-hati, sedangkan nilai 0,3 berartimemperbesar sistem yang lebih responsive.

Tabel 2 menunjukkan model terbaik pada peramalan kejadian hipertensi di puskesmas Bareng Kota Malang diperoleh dari nilai $\propto=0,3 \beta=0,1$ dan $\gamma=0,2$ yang menghasilkan nilai $\mathrm{MAPE}=12,04$, MAD $=35,00$ dan MSE $=3806,39$ yang terkecil. Hasil tersebut didukung oleh penelitian Pratama, dkk (2016) tentang peramalan total pendapatan bea dan cukai dengan menggunakan double exponential smoothing dengan nilai akurasi peramalan terbaik yaitu MAPE sebesar
12,974\%, MAD sebesar 13.235,1957 dan MSE sebesar 330.096.599,2381 pada $\alpha \quad 0,140$. Penelitian Safitri , dkk (2017) tentang peramalan jumlah kedatangan wisatawan di Bandara Ngurah Rai Bali menyampaikan hal yang sama bahwa nilai model terbaik pada winters exponential smoothing diperoleh dari nilai $\propto=0,3 \quad \beta=0,1$ dan $\gamma=0,1$ diperoleh nilai MAPE sebesar 8,86198\%, MSE sebesar 1436553590.

\section{Autoregressive Integrated Moving Average.}

Hasil dari tahap awal analisis padamodel ARIMA adalah plot data time series.Plot data pada gambar 5.3 menunjukkan bahwa pada data kejadian hipertensi terdapat fluktuasi, sehingga dapat dikatakan data tidak stasioner terhadap ragam dan rata-rata, sehingga perlu untuk dilakukan transformasi data. Gambar 5.4 Box Cox Plot Kejadian Hipertensi hasil transformasi menunjukkan rounded value pada angka 1,00 artinya data telah stationer terhadap ragam, langkah selanjutnya adalah melakukan pengecekan stasioner data terhadap rata-rata.

Hasil plot ACF pada gambar 5.6 dan pada gambar 5.7 Plot PACF menunjukkan data telah stasioner pada differencing pertama artinya data dapat dimodelkan dengan ARIMA. Menurut Teapon (2015) agar dapat dimodelkan menggunakan ARIMA atau ARIMA faktor utama yang harus diperhatikan adalah data harus stasioner. Bila data stasioner dalam level maka data dapat dimodelkan dalam ARIMA. Apabila data stasioner dalam bentuk difference $\left(1^{\text {st }}\right.$ dan $\left.2^{\text {nd }}\right)$ maka data bisa dimodelkan dengan ARIMA. Data tidak stasioner pada level dapat ditunjukkan pada nilai Q stattistik Ljung Box (pada lag terakhir) yaitu 87,03 yang lebih besar nilainya dari nilai kritis Chi-Square ( dengan df sebesar 31

pada alpha 0,05 yaitu 24,2 Berdasarkan pola $\mathrm{ACF}$ dan PACF yang cenderung bersifat turun drastis atau cut of point dan stasioneritas data diperoleh pada differencing pertama, maka variabel kejadian hipertensi dapat dimodelkan dengan Autoregressive Integrated Moving Average (ARIMA) dengan ordo yang diperoleh dari pola ACF dan PACF yaitu $(3,1,1)$ dengan hasil yang diperoleh sebagai berikut: 
1. Residual sudah bersifat acak, dapat dilihat dari nilai Box Ljung yang memiliki nilai pvalue $=0,727 \quad 0,05$

2. Nilai koefesien MA dan AR $<1$, menunjukkan kondisi invertibilitas dan stasioneritas sudah terpenuhi

3. Proses iterasi sudah convergen yang ditunjukkan dengan kalimat "relative change in each estimate less than $0,0010 "$.

\section{Perbandingan Winter's Exponential Smoothing dan Autoregressive Integrated Moving Average}

Analisa peramalan data time series untuk kejadian hipertensi dengan menggunakan metode Winter's Exponential Smoothing memiliki kesamaan dalam langkah-langkah dan proses peramalan padametode peramalan Autoregressive Integrated Moving Average (ARIMA) yaitu diawali dengan mengidentifikasi model (menentukan plot scater), mengestimasi parameter, melakukan uji diagnosis dan melakukan prediksi.

Hasil peramalan menunjukkan bahwa kedua metode menunjukkan hasil peramalan yang cenderung menurun pada tahun 2018 dengan kejadian terendah pada bulan Desember yaitu dengan angka kejadian sejumlah 57,228 pada metode Winter's Exponential Smoothing dan sejumlah 80,210 pada metode Autoregressive Integrated Moving Average.

Berdasarkan nilai Mean Square Error atau MSE yang dihasilkan oleh kedua metode tersebut diperoleh bahwa metode Winter's Exponential Smoothing memiliki nilai MSE sebesar 3806,39 dan metode Autoregressive Integrated Moving Average memiliki nilai MSE sebesar 4202. Nilai MSE tersebut menunjukkan bahwa nilai MSE pada metode Exponential Smoothing Winter's lebih besar jikadibandingkan dengan nilai MSE padametode Autoregressive Integrated Moving Average artinya berdasarkan hasil MSE tersebut, maka metode Autoregressive Integrated Moving Average atau ARIMA memiliki kesalahan lebih kecil atau dengan kata lain nilai peramalan yang dihasilkan lebih akurat.

\section{Peramalan Kejadian Hipertensi}

Hasil peramalan kejadian hipertensi untuk tahun 2018 dengan menggunakan winters exponential smoothing menunjukkan adanya tren penurunan kejadian hipertensi selama tahun 2018. Adanya tren penurunan kejadian hipertensi dapat didukung oleh faktor eksternal berupa faktor lingkungan, khususnya pelayanan kesehatan masyarakat yang ada di Puskesmas Bareng. Berdasarkan data yang telah didapatkan, pelayanan kesehatan pada masyarakat Bareng (Puskesmas Bareng) telah melakukan berbagai upaya dalam tindakan preventif, promotif dan kolaboratif dalam penanganan masalah Hipertensi. Tindakantindakan tersebut berupa adanya kegiatan Prolanis dan Posyandu Lansia yang diperuntukkan bagi lansia yang diadakan secara regular dimana dalam kegiatan tersebut termasuk kegiatan penyuluhan tentang Hipertensi dan Senam Hipertensi bagi penderita Hipertensi (Puskesmas Bareng, 2018). Adanya tindakan pencegahan untuk penanganan Hipertensi ini dapat mempengaruhi pengetahuan dan perilaku masyarakat khususnya gaya hidup sehat pada pasien Hipertensi (Maulana, 2009).

\section{KESIMPULAN}

Penelitian kejadian hipertensi menunjukkan:

1. Hasil peramalan dengan menggunakan Winter's Exponential Smoothing menghasilkan model pemulusan eksponential data asli adalah $S_{t}=0,3 \frac{x_{t}}{l_{t-l}}+0,7\left(S_{t-1}+b_{t-1}\right)$,

pemulusan pola trend yaitu $b t=0,1\left(S_{t}-S_{t-1}\right)+0,9 b_{t-1} \quad$ dan pemulusan pola musiman yaitu $l_{t}=0,2\left(X_{t}-S_{t}\right)+0,8 l_{m t-12}$ dan peramalan untuk periode ke depan yaitu $F_{t+m}=S_{t}+b_{t} m+l_{m t-L+m}$

2. Hasil peramalan dengan metodeAutoregressive Integrated Moving Average mengarah pada nilai $(3,1,1)$

3. Akurasi peramalan diperoleh dari nilai error Mean Square Error (MSE) yang paling kecil yaitu pada metode Winter's Exponential Smoothing sebesar 3806,39.

4. Hasil peramalan menunjukkan bahwa kejadian hipertensi untuk tahun 2018 
cenderung mengalami penurunan pada metode Winter's Exponential Smoothing dan Autoregressive Integrated Moving Average, dengan angka kejadian terendah terjadi pada bulan Desember yaitu sebanyak sebanyak 57,228 58 kejadian untuk metode Winter's Exponential Smoothingdan $80,210 \sim 82$ kejadian untuk metode Autoregressive Integrated Moving Average.

\section{DAFTAR PUSTAKA}

Atmaja, L.S. (2009). Statistika untuk Bisnis dan Ekonomi. Yogyakarta. Penerbit

Balitbangkes, Depkes RI. (2006). Operational Study an Immunity-Based Intervention Program On Common Major Non Communicable Disease in Depok Indonesia . Jakarta: Depkes RI.

Baradero et al (2008). Klien Gangguan Kardiovaskulear: Seri Asuhan Keperawatan. Jakarta: EGC

Bonita R. (2001). Surveillance of Risk Factors for Non Communicable Disease; The WHO Stepwise Approach. Summary. Geneva; World Health Organization.

WHO/SEARO. (2005). Surveillance of Major Non Communicable Diseases in South East Asia region. Report of an Inter Country Consultation. Geneva; WHOSEARO.

CDC. (1991-1999). State Specific Trend in Self Report $3^{\text {rd }}$ Blood Pressure Screening and High Blood Pressure. United States.

WHO-ISH. (2003). Hypertension Guideline Committee. Guidelines of The Management of Hypertension. $\mathrm{J}$ Hypertension

Joint National Committee on Prevention, Detection, Evaluation, and Treatment of High Blood Pressure (JNC). (2003). The Seventh Report of The JNC (JNC7).

Departemen Kesehatan. (2004). Survei Kesehatan Nasional. Laporan Departeman Kesehatan RI. Jakarta.

Fretchling, D.c. (2001). Forecasting Tourism Demand: Methods and Strategies. Butterworth Heinemann, Oxford.

Basuki B, Setianto B. (2001). Age, Body, Posture, Daily Working Load Past Antihypertensive drug and Risk of
Hypertension ; a Rural Indonesia Study. Med J Indon.

Darmojo B. (2000). Mengamati Penelitian Epidemiologi Hipertensi di Indonesia. Disampaikan pada seminar hipertensi PERKI.

Setiawan, Zamhir. (2006). Karakteristik Sosiodemografi sebagai Faktor Resiko Hipertensi Studi di Pulau Jawa tahun 2004 (Tesis). Program Studi Epidemiologi Program pasca Sarjana FKM-UI. Jakarta.

Ginsberg, Lionel (2008). Lecture Notes Neurologi. Jakarta: Erlangga

Hankey, GJ. (2002). Hipertensi: Long Term Dissability After First Ever Hipertensi And Related Prognostic Factors In The Perth Community Hipertensi Study, 1998-1990.

Kuntoro, H. (2011). Dasar Filosofis Metodologi Penelitian. Zifatama, Sidoarjo.

Makridakis, S, dkk. 1999. Metode dan Aplikasi Permalan, Jilid I edisi kedua. Jakarta: Binarupa Aksara.

Makridakis, S., Wheelwright, S. C., McGee V. E., (1992). Forecasting: Methods andApplications, $2^{\text {nd }}$ edition. John Wiley \& Sons Inc.

Mulyana. (2013). Penyakit Infeksius dan non infeksius

http://yuzniemulyhana.blogspot.co.id/2 013/10/penyakit-non-infeksi.html. 6 okt 2013. Diakses pada 3 Nopember 2017.

Tambayong, Jan (2000). Patofisiologi untuk Keperawatan. Jakarta: EGC

Wei, W.W.S. (2006). Time Series univariat and Multivariat Methods. $2^{\text {nd }}$ United States Of America: Pearson Education.

WHO (2008). Fact Sheet : The Top Ten causes Of Death. 28 Oktober 2017. www.who.int/mediacentre/factsheets/fs 310_2008.pdf.

Wilterdink JL, Easton JD. (2001). Hipertensi Prevention In 2001. In: Bougosslavsky J. ed. Drug Theraphy For Hipertensi Prevention. London ; Taylor And Francis.

Yastroki. (2009). Hipertensi Urutan Kedua Penyebab Kematian di Indonesia, www.yastroki.or.id 
